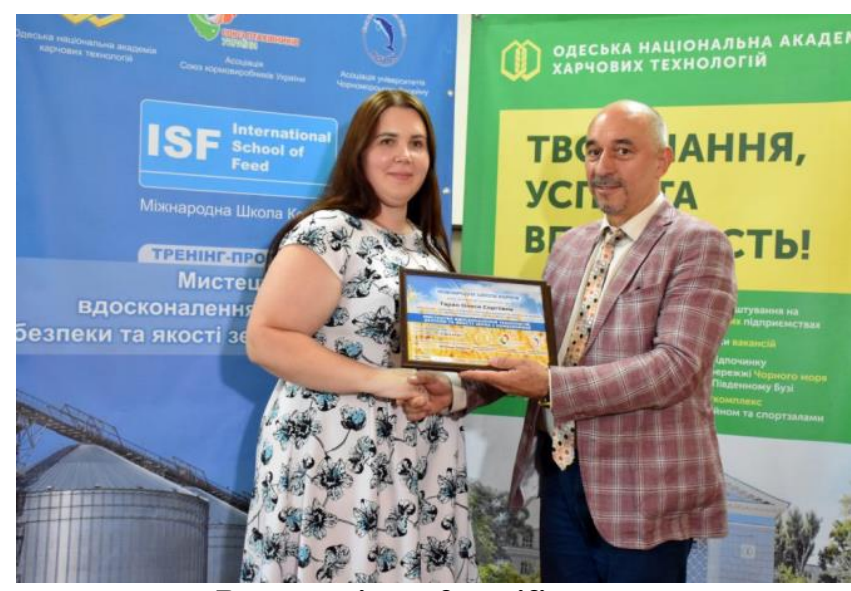

Presentation of certificates
An excursion around the city of Odessa was organized for the participants, the participants attended the ballet "Kyiv Modern Ballet Carmen "at the Odessa National Academic Opera and Ballet Theater and the Shustov Cognac Museum.

For seven years, the International School of Feed has been changing and constantly keeping pace with the requirements of the times and the needs of enterprises in the feed industry. The positive feedback from the participants on the level of the Seventh Session of the International School of Food shows that the high tasks set by the Scientific Council of the International School of Food are being fulfilled in full.

Liudmyla FIHURSKA, PhD, Associate Professor Received 12.06.2021. Approved 24.06.2021

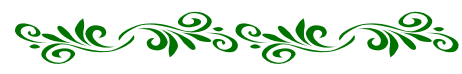

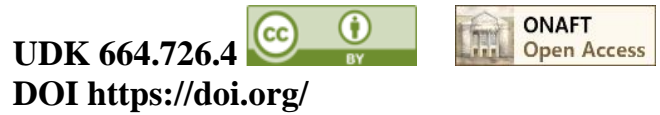

L. Soldatenko, PhD. tech. Sciences, Associate Professor, E-mail: leonid541247@ gmail.com ORCID 0000-0003-4423-088X Researcher ID: U-7423-2017

A. Shipko, Post-graduate student,E-mail: shipko.arkadiy@gmail.com ORCID 0000-0002-5665-1748 Researcher ID: M-1249-2016 I. Shipko, PhD tech. Sciences, Associate Professor, E-mail: shipkoigor@gmail.com ORCID 0000-0003-4148-397X, Researcher ID: U-3829-2017

Odessa National Academy of Food Technologies, 112, Kanatna Str., Odessa, 65039, Ukraine, +380487124113

\title{
ATTEMPT TO IMPROVE THE OPERATING AND TECHNOLOGICAL PROPERTIES OF THE COMBINED GRAIN WASHING MACHINE
}

\begin{abstract}
Washing machines are used in the production lines of grain cleaning departments of flour mills for thorough cleaning of the grain surface, in particular, its grooves from the remnants of organic and mineral dust, microorganisms and mold. In addition, the grain mass during washing is cleaned of hydrodynamically light and heavy impurities - chaff, seeds of waste plants, straw fragments, mineral particles in the form of sand, small stones, lumps of earth, as well as spores and wormwood seeds. At the same time, foreign odors of grain disappear.

Experience in the operation of Ж9-БMA machines shows that along with many advantages, they have some disadvantages. In particular, the productivity of the machine $10 \mathrm{t} / \mathrm{h}$ does not correspond to the productivity of the conjugated technological equipment of the production line, and the specific water consumption for washing grain is $1.8 \ldots 2.0 \mathrm{l} / \mathrm{kg}$, which is too much in modern conditions of acute shortage of drinking water. Enterprises to abandon the use of washing machines. In addition, certain problems and inconveniences are caused by the design of the sieve shell of the impression column. Stamped sieves with scaly asymmetric holes have a low coefficient of living cross section, which complicates the process of dehydration of washed grain, quickly corrode and rub, require special attention during installation or replacement. Therefore, an attempt is made to eliminate these shortcomings.

In particular, the reduction of water consumption is achieved due to the elimination of the grain hydraulic conveyor during its transfer from the washing bath to the pressure column. For this purpose, a device for mechanical overloading of grain by a rotary bucket device located within the alloy chamber is used. At the same time, attention was paid to the separation of light organic impurities from the grain. This decision needs further explanation.

The functional diagram shows that the initial grain mixture enters the receiving device, which feeds it with a minimum vertical speed into the ascending water streams created by the screws of two grain augers rotating with the same frequency in the opposite direction. The augers pick up the grain and, keeping it afloat in a suspended state, mix it with the water of the washing bath. At the same time the grain is washed and particles are separated from it, which differ from it in terms of density: mineral impurities begin to sink, fall down and through the longitudinal slit in the auger trough fall into the area of the auger for mineral impurities. This auger transports the "stones" in the opposite direction to the funnel with the ejector of the hydrotransporter of mineral particles. Light impurities, during the transportation of grain by grain augers, float to the surface of the water, the level of which in the washing bath is maintained up to the axis of the augers. Together with grain and water, these impurities are pushed out of the bath into the alloy chamber.
\end{abstract}


In the chamber, in the transverse direction, a pipe with a longitudinal absorption slot is installed, the lower edge of which is immersed in water so that the upper layer of water merges into this slot together with light impurities that have surfaced in the washing bath. The amount of water that fuses light impurities can be adjusted by the depth of immersion in water of the lower edge of the absorption hole. To do this, the pipe is rotated relative to its axis with a special handle with a clamp and a pointing scale. One end of the pipe is closed by a plug, and the other passes through a hole in the wall and drains the water with light impurities into the sink sump. The described device provides almost complete removal of light impurities and minimal consumption of floating water. This solution is in the invention according to the copyright certificate 701708404, developed by specialists of the department TOZV. In addition, certain problems and inconveniences are caused by the design of the sieve shell of the squeezing column. Dirt particles tend to stick to the outer surface of the sieve cylinder and block its holes. This can slow down and even stop the separation of water by centrifugation. Therefore, the upper outer surface of the cylinder is washed with water, which in automatic mode is periodically fed to the sieve by the control device and the solenoid valve. It also saves water.

Key words: grain washing machine; reduction of water consumption for grain washing; improved washing machine; modernization of the washing machine; grain washing.

\section{Introduction}

Washing machines are used in the production lines of grain cleaning departments of flour mills for thorough cleaning of the grain surface, in particular, its grooves from the remnants of organic and mineral dust, microorganisms and mold. In addition, the grain mass during washing is cleaned of hydrodynamically light and heavy impurities - chaff, seeds of waste plants, straw fragments, mineral particles in the form of sand, small stones, lumps of earth, as well as spores and wormwood seeds. At the same time, foreign grain odors disappear [1].

The efficiency of washing machines is characterized by the following indicators: reduction of grain ash content by $0.02 \ldots 0.05 \%$; increase in humidity by $1.5 \ldots$ $3 \%$; increasing the content of broken grain to $1 \%$; extrac-

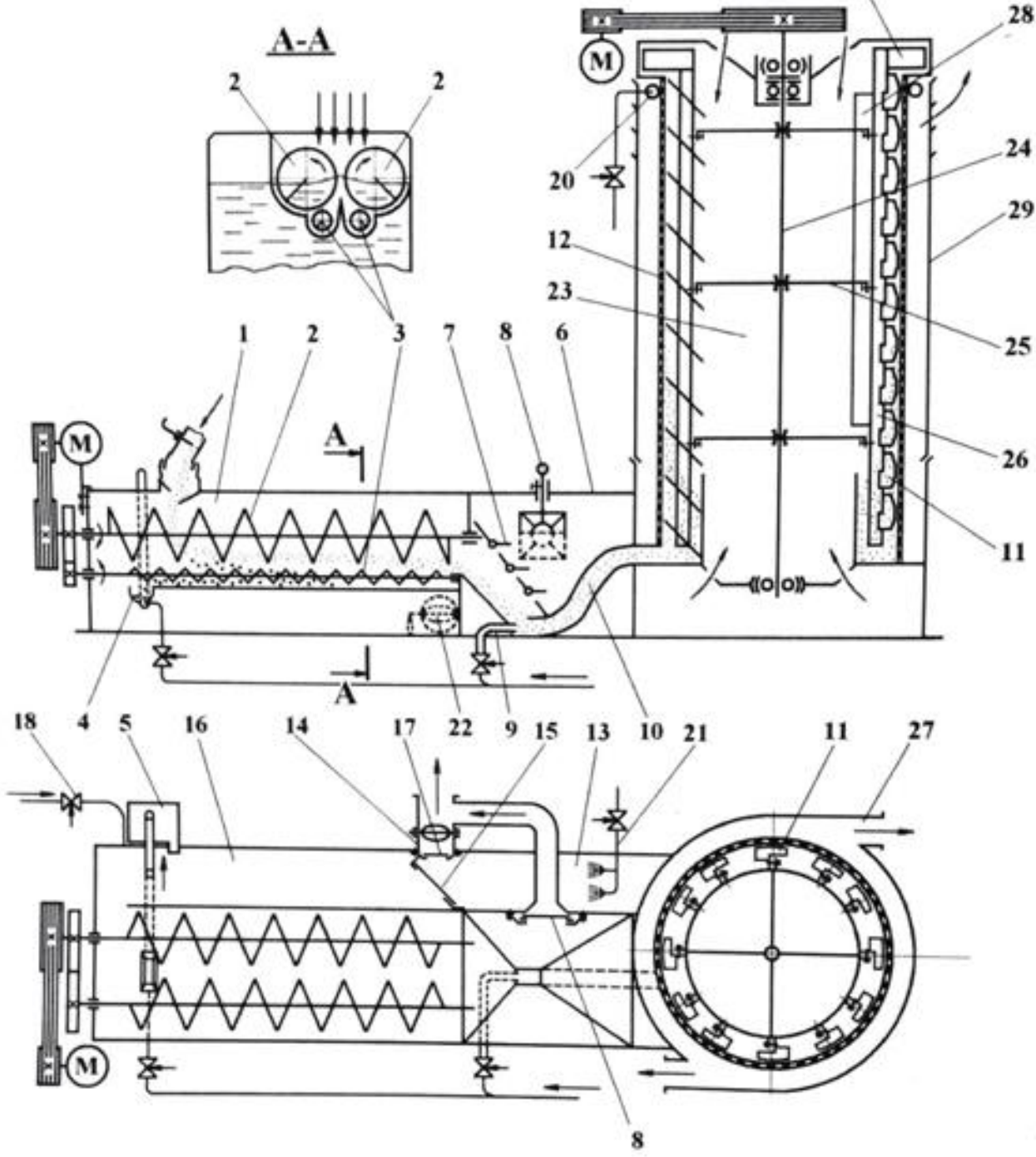

Fig. 1. Combined washing machine Ж9-БМА: 1 - washing bath; 2 - grain auger; 3 - auger for stones; 4 - hydroseparator of stones; 5 - collection of stones accumulator; 6 - floatable chamber; 7 - inclined partition; 8 - water

level regulator; 9 - nozzle; 10 - pipe of the hydrotransporter of grain; 11 - blade of the squeezing column;

12 - sieve shell; 13 - dirty water receiver; 14 - valve box; 15 - water level regulator; 16 - sump; 17 - gate valve; 18 - valve; 19 - grain unloader blade; 20 - ring-shaped pipeline; 21 - defoamer; 22 - throttle valve; 23 - squeezing column; 24 - shaft; 25 - fastening disk; 26 - scourge; 27 - outlet pipe; 28 - ventilation blade; 29 - casing 
tion of light organic impurities in the range of $75 \ldots$ $100 \%$ and dense mineral $-70 \ldots 100 \%$. The amount of waste generated is $0.2 \ldots 0.5 \%$ by weight of processed grain $[2 ; 5]$.

\section{Research methodology}

Washing of grain and its simultaneous moistening in the combined washing machines together with the subsequent dehumidification, belong to the main processes of preparation of grain for grinding as there is not only clearing of grain of impurity, but also structuralmechanical and chemical-biological changes and transformation that facilitates separation of shells from the endosperm with minimal losses and improves the baking properties of flour. For this purpose, combined washing machines were created and used for a long time at domestic and foreign enterprises, in particular, models Ж9БMA of the Dnipropetrovsk plant "Prodmash" (Fig. 1). Some companies (for example, in Turkey) still continue to manufacture and use combined washing machines [3]; Prodmash plant also manufactures such machines to individual orders. Experience of operation of Ж9-БМА machines shows that, along with many advantages, they have some disadvantages: theoretically the productivity of the machine $10 \mathrm{t} / \mathrm{h}$ does not correspond to productivity of the conjugated technological equipment of highperformance production lines, and specific consumption of water for grain washing impurities of organic origin is $1.8 \ldots 2.0 \mathrm{l} / \mathrm{kg}$, which is too much in modern conditions of acute shortage of drinking water, and forces some companies to abandon the use of washing machines. In addition, certain problems and inconveniences are caused by the design of the screen shell of the squeezing column. Stamped sieves with scaly asymmetric holes have a small coefficient of living cross section, which complicates the process of dehydration of washed grain; sieves quickly corrode and wear out. The blades of the rotor squeeze column are attached to the plates by welding, so their replacement is possible only together with the plates. Given the above, our work proposes ways to eliminate these shortcomings.

Reduction of water consumption is achieved due to the elimination of the grain hydraulic conveyor during its transfer from the washing bath to the squeezing column; instead, a device for mechanical overloading of grain by a rotary bucket device located within the alloy chamber is used. Due to the fact that recently there have been highly efficient grain cleaning machines, first of all, vibro-pneumatic stone pickers, the content of mineral impurities (stones) in the grain entering the washing machines has decreased. Therefore, there is no need for two augers and two hydraulic conveyors to remove stones from the sink; instead, it is advisable to install only one auger and one hydraulic conveyor, which also reduces water consumption. Manual control of the flushing device of the screen shell of the squeezing column must be replaced by automated, which provides periodic supply of flushing water, how it is done when washing and peeling grain in А1-БМШ machines.

Another reserve for a significant reduction in water consumption is associated with the improvement of the device for the separation of hydrodynamically light impurities. For this purpose it is expedient to use the technical solution of the invention "Grain washing machine" according to the author's certificate 701708404 [4]. According to this solution, at the end of the washing bath (hydroseparator) two planes 10 are installed, which direct the washed grain with water and light impurities into the rafting chamber (Fig. 2). The grain, deprived of the transport action of the augers, is immersed in water, and water, more precisely, its upper layer, together with light impurities floating to the surface, enters the longi-

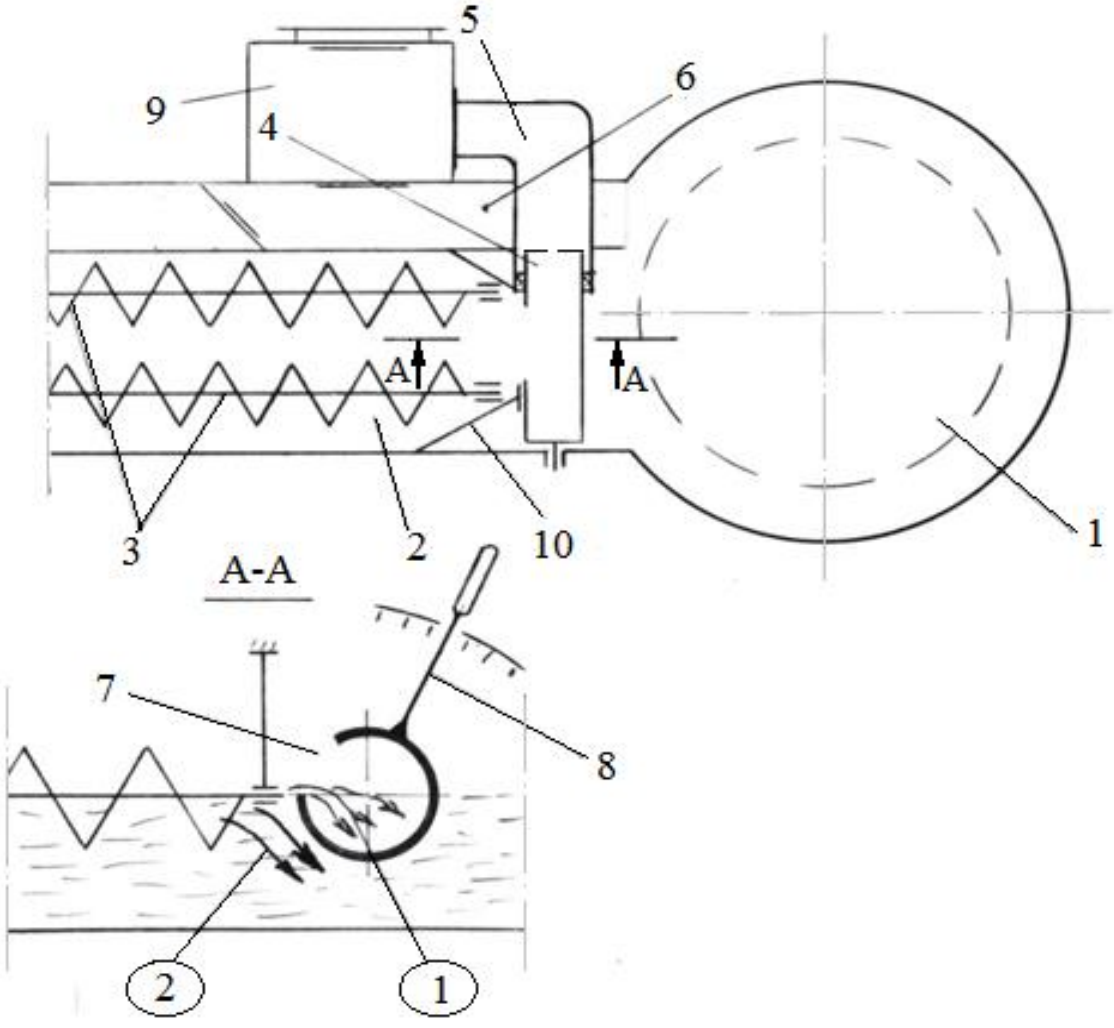

Fig. 2. Diagram of the washing machine according to the invention No. 1708404:

1 - squeezing column;

2 - washing bath (hydroseparator);

3 - grain auger;

4 - a pipe with a slot;

5 - branch pipe for extraction of light impurities; 6 - side compartment of the hydroseparator;

7 - longitudinal slit (slot);

8 - regulator;

9 - sump;

10 - plane;

(1) - the upper layer of water with light impurities; (2) - grain. 
tudinal slit (slot) 7 of the absorption pipe 4 , the axis of which is normal to the longitudinal axis. The lower edge of the slot of the pipe is immersed in water so that in this slot merged the upper layer of water (1) together with light impurities, that surfaced in the sink. The amount of water that fuses light impurities can be adjusted by the depth of immersion in water of the lower edge of the absorption hole. To do this, the pipe is rotated relative to its axis by a special handle 8 with a clamp and a pointingscale. One end of the pipe is closed by a plug, and the other is connected to the pipe 5, which drains water with light impurities into the receiver-settler 9 of dirty water coming from the squeezing column. The described device provides almost complete removal of light impurities and minimal consumption of floating water. This is facilitated by the appropriate adjustment of the height of the lower edge of the absorption opening of the pipe: the greater the content of light impurities on the water surface, the lower this edge, focusing on the divisions of the scale, and vice versa. Accordingly, the flow of floating water is regulated.

The washed grain (2) coming out of the washing bath is immersed in water, passes under the absorbing pipe and enters the tank of the rotary reloader on the inclined plane (Fig. 3). It has six buckets 12 arranged evenly around the circumference of the rotor 11, which rotates towards the squeezing column. The buckets are filled with water-grain mixture. The water partially passes through the holes in the side walls of the buckets, which are made of a stamped sieve with holes with a diameter of $1.7 \mathrm{~mm}$, and on the surface of the visors reflects 13 into the tank, where through the mesh partition passes into the channel connected to the settling tank. The water partly comes out together with light impurities coming from the outlet pipe, and partly gets into the settling chamber, after which it is recycled to the washing bath. Wastewater is treated on the sieves of the grain catcher, and then sent to the sewer. The separated organic matter is dehydrated by pressing and drying and sold for feed needs. The grain that falls out of the buckets of the loader, falls into the receiving pipe of the impression column and fills its lower part, where it falls under the influence of the lower row of mesh whip rotor (Fig. 4). The blades mix it intensively with water, continuing the washing process, and at the same time lift it up to the dehydration zone. This zone is formed by a fixed sieve shell, which externally covers the whip rotor with a radial gap of $6 \mathrm{~mm}$ The process of dehydration of washed grain is due to the following factors: natural flow of water down under the influence of gravity, centrifugation under the action of centrifugal inertia and aeromechanical removal of a certain amount of water by air current blowing the mobile grain layer due to the fan effect of the blades.

Drops of water, which go outside the sieve shell, facilitate the passage through the holes of the sieves of fragments of fruit shells and dirt, separated from some grains due to their rubbing on the rough sieve surface. Particles of shells and dirt tend to stick to the outer surface of the sieve cylinder and block its holes. This can slow down and even stop the dehydration of the grain. Therefore, the outer surface of the cylinder is rinsed with water, which is periodically fed to the sieve by the control device and the solenoid valve. Rinsing lasts 1 minute with an interval of 17 minutes. This is enough to restore the filtration capacity of the sieve with a minimum flow of flushing water in order to save it. Flushing water with sinks and dirt flows down and from the column into the flushing bath, where the wastewater settling process and partial water recirculation take place.

The sieve shell must be made of a special metal mesh of high wear resistance. Stainless faceted wire is used to make the mesh, which gives the sieve the necessary roughness and durability. The holes of the sieve with dimensions of $1.0 \times 1.8 \mathrm{~mm}$ have a symmetrical design and, unlike scaly, do not require special orientation relative to the direction of rotation of the whip-whip rotor during assembly or repair work. Since the coefficient of the living cross section of the grid is higher than that of the scaly sieve, the process of grain dehydration is much more efficient.

\section{Research results}

In some ways, the design of the whip rotor blades has also been improved. If, before the modernization, the blades were fastened to the plates with rivets, which made it impossible to replace them, then in our work the fastening is carried out with bolts. In addition, the design of the shoulder blades is now different, it is more convenient during assembly or repair operations and involves, if necessary, individual replacement of a shoulder blades. Figure 4 shows a functional diagram of a combined washing machine, which is built taking into

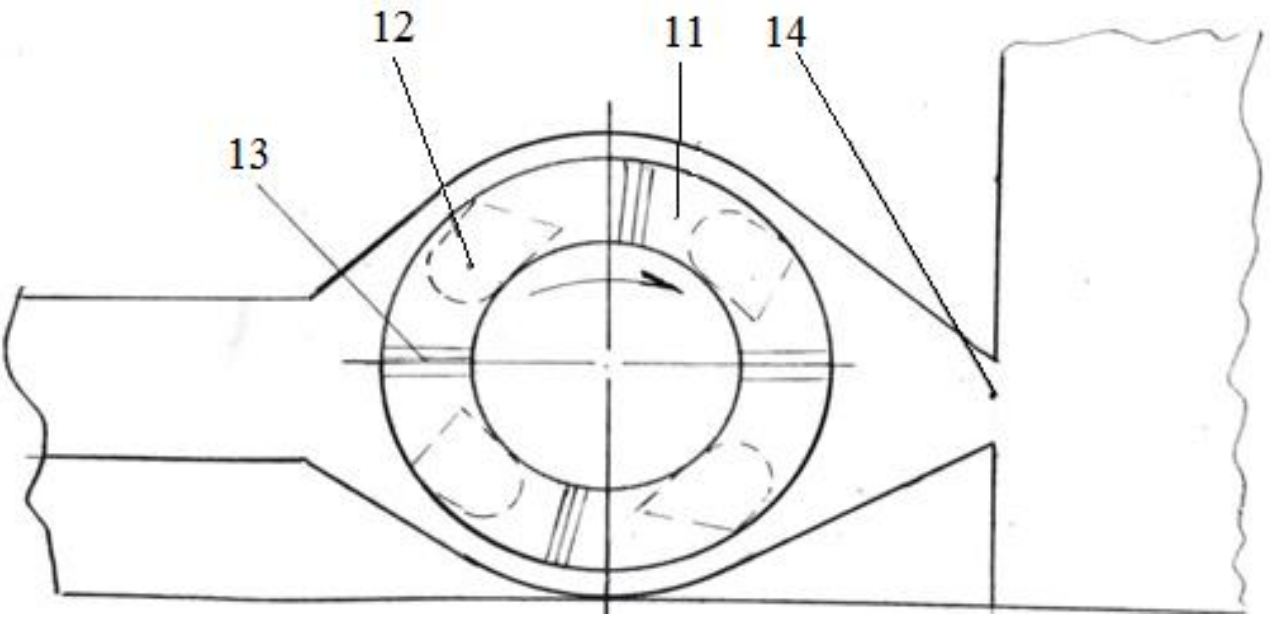

Fig. 3. Rafting chamber without hydraulic conveyor:

11 - bucket-type rotary reloader; 12 - perforated (mesh) bucket; 13 - water reflector (screen); 14 - window. 


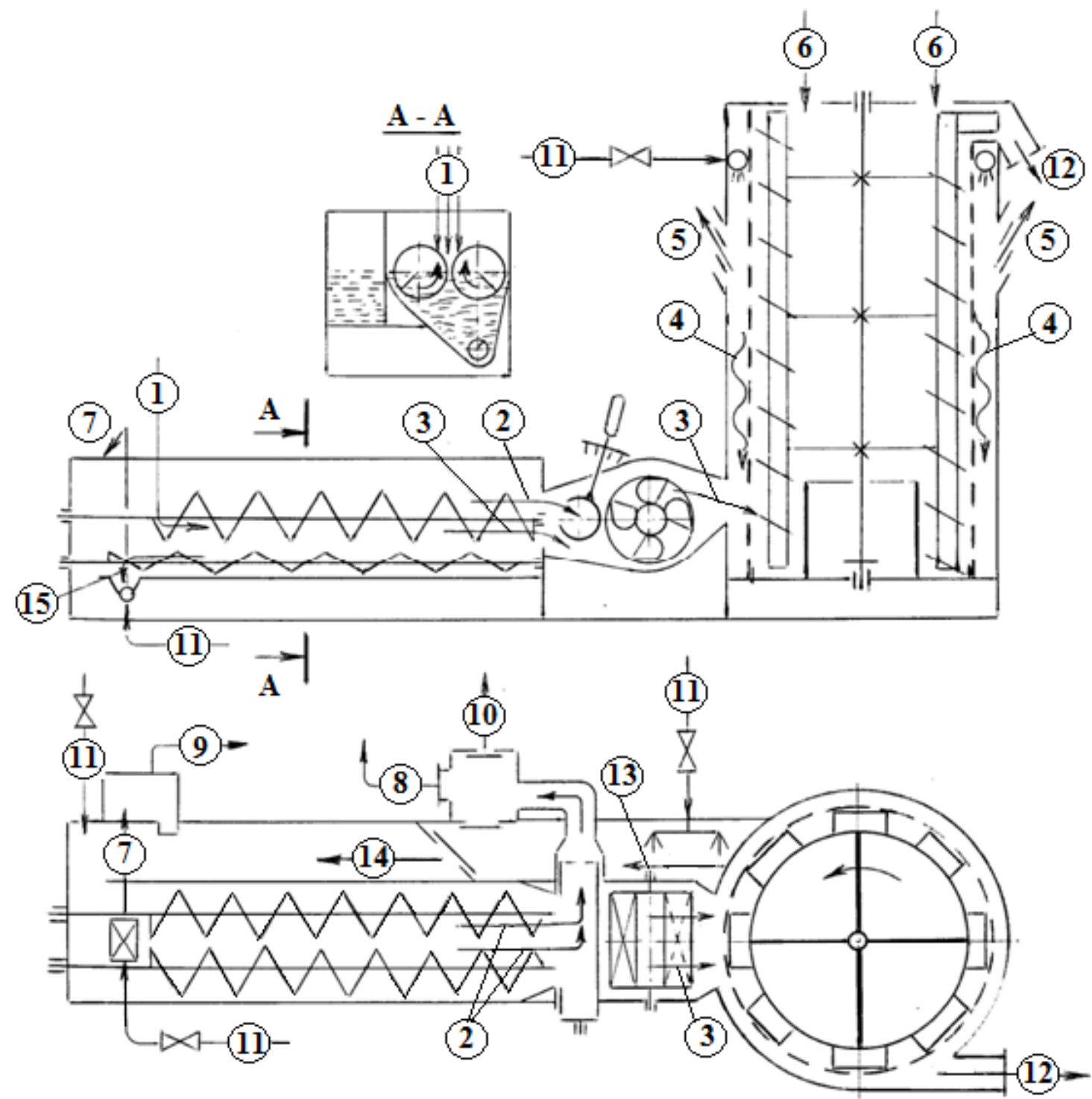

Fig. 4. Functional diagram of the improved washing machine Ж9- БМА:

(1) - incoming grain; (2) - water with light impurities; (3) - grain with water; (4) - water with shells; (5) - humid air; (6) - outside air; (7) - water with stones; (8) - sludge; (9) - mineral impurities (stones);

(10) - light impurities with water; (11) - water from the water supply network; (12) - refined grain;

(13) - waste water from the squeezing column; (14) - waste water for sedimentation and recirculation;

(15) - mineral impurities in the hydraulic conveyor

account the improvements made. The performance of the combined washing machine depends on the performance (capacity) of the squeezing column - $Q_{k}$, which can be determined by the expression

$$
Q_{k}=60 \frac{\pi\left[\left(D^{2}-d^{2}\right]\right.}{4} \times S \times n \times \gamma=\delta \times \mathrm{K}_{\mathrm{t}}=\mathrm{K}_{F} \frac{\mathrm{Kr}}{\mathrm{rom}}{ }^{*}
$$

де $D_{v} d$ i $S$ - outer, inner diameter and helical pitch the trajectory of the annular layer of grain, which moves the blades on the inner surface of the sieve shell, m; n speed of rotation of the whip rotor, rpm;

$\gamma$ - volume weight of the processed mix of grain with water, $\mathrm{kg} / \mathrm{m} 3$;

$\delta$ - coefficient of loosening of the grain mixture by rotor messengers; $K_{t}$ and $K_{F}$ are the discontinuity coefficients of The helical surface created by the rotor blades is shown along its axis and in the transverse direction. The coefficient $K_{t}$ is equal to

$$
\mathrm{K}_{\mathrm{t}}=\frac{\sqrt{\mathrm{n} \cos \mathrm{c}}}{\mathrm{t}} \text {. }
$$

where 1 is the length of the blade, m; $\alpha$ - the angle of the mesh relative to the axis of the rotor, deg;

$\mathrm{t}$ - is the longitudinal pitch of the blades, $\mathrm{m}$

The coefficient $\mathbb{K}_{F}$ is equal to

$$
\mathrm{K}_{F}=\frac{1-\sin \omega Z_{F}}{\pi \cdot D_{\text {top }}} \text {, }
$$

where $Z_{F}$ is the number of blades in the crosssectional plane of the rotor; $D_{\text {cep }}$ - the average diameter of the whip-whip rotor $\left(D_{\text {cep }}=\frac{D-d}{2}, \mathrm{M}\right)$.

If to accept (according to technical characteristics of the Ж9-БМА washing machine) $\mathrm{D}=0,907 \mathrm{~m}$; $\mathrm{d}=0.895 \mathrm{~m} ; \mathrm{S}=1,905 \mathrm{~m} ; \mathrm{n}=400 \mathrm{rpm} ; \delta=0.5$; $\gamma=910 \mathrm{~kg} / \mathrm{m}^{3} ; 1=0.175 \mathrm{~m} ; \alpha=450 ; Z_{F}=12 ; \mathrm{t}=1,782 \mathrm{~m}$, then we obtain coefficients $K_{t}=0,069$ and $K F=0,519$ and the performance of the impression column 
$Q_{k} \approx 47.1\left(\mathrm{D}^{2}-\mathrm{d}^{2}\right) \cdot \mathrm{S} \cdot \mathrm{n} \cdot \gamma \cdot \delta \cdot \mathrm{K}_{\mathrm{t}} \cdot \mathrm{K}_{F} \approx 47.1(0.9072-$

$0.8952) \cdot 1.905 \cdot 400 \cdot 910 \cdot 0.5 \cdot 0.069 \cdot 0.519$

$\approx 12698 \mathrm{~kg} /$ hour

that is, the productivity of the combined washing machine Ж9-БMA after improvement according to the described method $Q \approx 12 \mathrm{t} / \mathrm{h}$.

\section{Conclusions}

Along with saving water for grain washing and improving the design, this indicates the possibility and feasibility of modernization and further use of combined washing machines in high-performance enterprises in the industry.

\section{REFERENCES}

1. Gaponyuk O.I., Soldatenko L.S., Grosul L.G. et al. Technological equipment of flour and cereal enterprises. Kherson: Oldi-plus, 2018. -752 p.

2. Merko I.T., Morgun V.O. Scientific bases and technology of grain processing. - Odessa: Druk, 2001. - 348 c.

3. Demsky A.B., Vedenyev V.F. Equipment for the production of flour, cereals and animal feed. Directory. -M .: DeLi print, 2005. $-760 \mathrm{p}$.

4. Georgi N.V., Skichko S.S., Kravchenko G.K., Soldatenko L.S., Steinschleiger A.S. Grain washing machine. Author's certificate for the invention № 1708404 .

5. Rules for organizing and conducting the technological process at flour mills. Kiev. VIPOL. 1998.

\section{УДК 664.726.4}

Л.С. Солдатенко, канд. техн. наук, доцент, E-mail: leonid541247@gmail.com ORCID 0000-0003-4423-088X Researcher ID: U-7423-2017 А.I. Шипко, аспірант, E-mail: shipko.arkadiy@ gmail.com ORCID 0000-0002-5665-1748 Researcher ID: M-1249-2016

I.М. Шипко, канд. техн. наук, доцент, E-mail: shipkoigor@gmail.com ORCID 0000-0003-4148-397X, Researcher ID: U-3829-2017 Одеська наиіональна академія харчових технологій, вул. Канатна, 112, Одеса, 65039, Украӥна, +380487124113

\section{ПОЛІПШЕННЯ ЕКСПЛУАТАЦІОННО- ТЕХНОЛОГІЧНИХ ВЛАСТИВОСТЕЙ КОМБІНОВАНОЇ МИЙНОЇ МАШИНИ ДЛЯ ЗЕРНА}

\section{Анотація}

Мийні машини застосовують у складі потокових ліній зерноочисних відділень борошномельних заводів для ретельного очищення поверхні зерна, зокрема, його борозенки від залишків органічного і мінерального пилу, мікроорганізмів і плісняви. Окрім того, зернова маса під час миття очишується від гідродинамічно легких і важских домішок - полови, насіння смітних рослин, уламків соломи, мінеральних частинок у вигляді піску, дрібного каміння, грудочок землі, а також від спор головні $і$ насіння полину. Одночасно зникають сторонні запахи зерна.

Ефективність дії мийних машин характеризують такими показниками: зменшенням зольності зерна на 0,02...0,05\%; збільшенням вологості на 1,5...3\%; збільшенням вмісту битого зерна до 1\%; вилученням легких органічних домішок у межах 75 ...100\% та щүільних мінеральних - 70...100\%. Кількість відходів, щчо створюються, складає 0,2 ...0,5\% від маси обробленого зерна.

Прочес миття зерна і одночасне його зволоження, разом з подальшим відволожуванням, відносяться до основних прочесів підготовки зерна до помелу, оскільки при ицьому відбувається не тільки очищення зерна від домішок, але й структурно-механічні і хіміко-біологічні змінення і перетворення. Це полегшує відокремлення оболонок від ендосперму з мінімальними його втратами і покращує хлібопекарські властивості борошна.

Досвід експлуатачії машин Ж9-БМА свідчить про те, щчо поряд з багатьма перевагами вони мають деякі

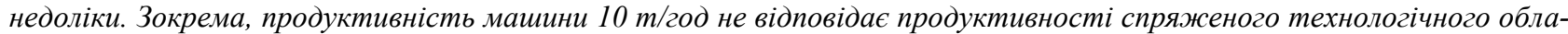
днання потокової лінії, а питома витрата води на миття зерна складає 1,8...2,0 л/кг, шуо забагато в сучасних умовах гострого дефіциту господарсько-питної води і примушує деякі підприємства відмовлятись від застосування мийних машин. Окрім иьього, певні проблеми і незручності викликає конструкція ситової обичайки відтискної колонки. Штамповані сита з лускоподібними несиметричними отворами мають замалий коефіиієнт живого перерізу, щзо ускладнює процес зневоднення митого зерна, ивидко кородують і протираються, потребують підвищеної уваги під час монтажу або заміни. Тому в роботі зроблено спробу усунути иі недоліки.

Скорочення витрати води досягнуте за рахунок ліквідаџії гідротранспортера зернової маси при ії передачі з мийної ванни у відтискну колонку. Для иього застосовано пристрій для механічного перевантаження зерна роторним ковшовим пристроєм, розташованим у межах сплавної камери. Одночасно, було приділено увагу відокремленню від зерна легких органічних домішок. Це рішення потребує додаткових пояснень. На функиіональній схемі показано, щчо вихідна зернова суміш надходить у приймальний пристрій, який подає ї̈ з мінімальною вертикальною швидкістю у висхідні потоки води, створені гвинтами двох зернових шнеків, щзо обертаються з однаковою частотою в протилежному напрямку. Шнеки підхоплюють зерно $і$, підтримуючі його на плаву у підваженому стані, перемімують 3 водою мийної ванни. Одночасно відбувається миття зерна і відокремлення від нього частинок, які відрізняються від нього за ознакою густини: мінеральні домішки починають тонути, опускаються донизу і крізь поздовжню щілину у кориті шнеків потрапляють у зону дії шнека для мінеральних домішок. Цей шнек транспортує «каміння» у проти- 
лежному напрямі до воронки з ежектором гідротранспортера мінеральних частинок. Легкі домішки, під час транспортування зерна зерновими шнеками, спливають на поверхню води, рівень якої у мийній ванні підтримується до осі шнеків. Разом з зерном і водою изі домішки виштовхуються з ванни до сплавної камери.

У камері, в поперечному напрямі, встановлена труба з поздовжнім поглинальним прорізом, нижня кромка якого занурена у воду таким чином, щзоб у цей проріз зливався верхній шар води разом з легкими домішками, щэо сплили на поверхню у мийній ванні. Кількість води, яка сплавляє легкі домішки, можна регулювати глибиною занурення у воду нижньої кромки поглинального отвору. Для иьього трубу повертають відносно ї̈ осі спеціальною рукояткою $з$ фіксатором і вказівною шкалою. Один кінець труби закриває заглушка, а другій проходить крізь отвір у стінці $і$ зливає воду з легкими домішками у відстійник мийної ванни. Описаний пристрій забезпечує майже повне вилучення легких домімок і мінімальну витрату сплавної води. Це рімення знаходиться у винаході по авторському свідоцтву №1708404, розробленому фахівиями кафедри ТОЗВ. Зерно, щзо виходить з мийної ванни, зануряється в воду і по похилій площині надходить у резервуар роторного перевантажувача з шістьма ковшами, розташованими рівномірно по окружності ротора, який обертається у напрямку до відтискної колонки. Ковші заповнюються водно-зерновою сумішшю. Вода частково проходить крізь отвори бокових стінок ковшів, які виготовлені зі штампованого сита 3 отворами діаметром 1,7 мм. Вода по поверхні козирків-відбивачів зливається у резервуар, звідки крізь сітчасту перегородку проходить у канал, який сполучається з відстійником і евакуаційно-зливним патрубком. Вода частково виходить назовні разом з легкими домішками, а зерно з залишками води надходить у відтискну колонку, де його інтенсивно перемішують і додатково піддають миттю гінці бичового ротора і одночасно піднімають вгору, в зону зневоднення. Ця зона сформована нерухомою ситовою обичайкою, яка ззовні охоплює бичовий ротор з радіальним зазором у 6 мм. Процес зневоднення митого зерна відбувається внаслідок дії таких факторів: природного стікання води вниз під впливом сили тяжіння; центрифугування під дією відцентрових сил інерції і аеромеханічного відбирання певної кількості води повітряним струмом, який продуває мобільний зерновий шар внаслідок вентиляторного ефекту лопатей, закріплених в центральній частині бичового ротора.

Краплі води, які виходять назовні ситової обичайки, сприяють проходженню крізь отвори сит фрагментів плодових оболонок, відокремлених від деяких зерен внаслідок їх протирання по шорсткій ситовій поверхні. Частинки оболонок $і$ бруду мають тенденцію налипати на зовнішню поверхню ситового циліндра і блокувати його отвори. Це може уповільнити і навіть припинити відокремлення води шляхом центрифугування. Тому верхня зовнішня поверхня циліндру піддається промиванню водою, яка в автоматичному режимі періодично подається на сито командним приладом і електромагнітним вентилем. Це також сприяє заощадженню води.

Ключові слова: мийна машина для зерна; зниження витрати води на мийку зерна; вдосконалена мийна машина; модернізація мийної машини; мийка зерна.

\section{ЛІТЕРАТУРА}

1. Гапонюк О.І., Солдатенко Л.С., ГросулЛ.Г. $і$ інш. Технологічне обладнання борошномельних $i$ круп'яних підприємств. -Херсон: Олді-плюс, 2018. -752 c.

2. Мерко І.Т., Моргун В.О. Наукові основи і технологія переробки зерна - Одеса: Друк, 2001. - 348 с.

3. Демский А.Б., Веденьев В.Ф. Оборудование для производства муки, крупы и комбикормов. Справочник. -М.: ДеЛи принт, 2005. - $760 \mathrm{c}$.

4. Георги Н.В., Скичко С.С., Кравченко Г.К., Солдатенко Л.С., Штейншлейгер А.С. Моечная машина для зерна. Авторское свидетельство на изобретение № 1708404.

5. Правила організації і ведення технологічного прочесу на борошномельних заводах. Київ. ВІПОЛ. 1998.

\section{Received 19.03.2021 \\ Reviewed 03.04.2021}

Revised 22.04.2021

Approved 24.06.2021

\section{Cite as Vancouver Citation Style}

Soldatenko L., Shipko A., Shipko I. Attempt to improve the operating and technological properties of the combined grain washing machine. Grain products and mixed fodder's, 2021; 21 (2, 82):7-13. DOI https://doi.org/10.15673/

\section{Cite as State Standard of Ukraine 8302:2015}

Attempt to improve the operating and technological properties of the combined grain washing machine. / Soldatenko L. et al. // Grain Products and Mixed Fodder's. 2021. Vol. 21, Issue 2 (82). P. 7-13. DOI https://doi.org/10.15673/

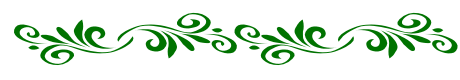

